\title{
BOGOTÁ: ROSTROS DE MARGINACIÓN Y DELINCUENCIA JUVENIL EN TRES CUENTOS DE LUIS FAYAD*
}

\author{
BOgotÁ: FACES OF MARGINALIZATION AND \\ JUVENILE OFFENDING IN THREE STORIES BY \\ LUIS FAYAD
}

Álvaro Antonio Bernal ${ }^{1}$

\begin{abstract}
* Artículo derivado de un proyecto sobre representaciones literarias de Bogotá en los últimos cincuenta años, y del cual se han publicado dos libros teóricos: Percepciones $e$ imágenes de Bogotá (dos ediciones, $2010 \mathrm{y}$ 2018) y Bogotá: realidades, delirios y ficciones (2016).
\end{abstract}

Cómo citar este artículo: Bernal, A. A. (2021). Bogotá: rostros de marginación y delincuencia juvenil en tres cuentos de Luis Fayad. Estudios de Literatura Colombiana 48, pp. 245-262. DOI: https://doi.org/10.17533/ udea.elc.n48a15

1 https://orcid.org/0000-0001-5053-7568 alvaro.bernal@pitt.edu

University of Pittsburgh at Johnstown, United States

Editores: Andrés Vergara Aguirre, Christian Benavides Martínez, Valentina Noreña Gómez

Recibido: 10.08 .2020

Aprobado: 21.10 .2020

Publicado: 18.12 .2020

Copyright: @2021 Estudios de Literatura Colombiana. Este es un artículo de acceso abierto distribuido bajo los términos de la Licencia Creative Commons AtribuciónNo comercial - Compartir igual 4.0 Internacional
Resumen: a través de su narrativa el escritor colombiano Luis Fayad ha estado ligado a la temática urbana. Varias de sus obras examinan el tejido social de una Bogotá fragmentada. Este estudio se ocupa de tres cuentos en los que Fayad reflexiona sobre la marginalidad urbana a partir de jóvenes personajes que delinquen en las calles. A pesar de su carácter ficcional, estos trabajos documentan la realidad marginal de Bogotá durante las décadas del sesenta y setenta. Los relatos escogidos, allende de sus méritos estéticos, establecen la memoria de la ciudad, evidencian proyectos sociales fallidos y un intento truncado de modernización.

Palabras clave: Luis Fayad; Literatura colombiana; Bogotá; Literatura urbana; marginalización.

Abstract: Through his literary work, Colombian writer Luis Fayad has been linked to urban themes. Several of his stories and novels revolve around the social fabric of a widely fragmented Bogotá. In this study, three short stories in which Fayad reflects on urban marginality are analyzed. The protagonists are minors who idly roam and live on the streets participating in unlawful behavior. These texts document the marginal reality that occurred in Bogotá over the sixties and seventies. These narratives, beyond their aesthetic merits, establish the memory of the city, revealing a failed social project, and an ineffective plan of modernization.

Keywords: Luis Fayad; Colombian Literature; Bogotá; Urban Fiction; City Marginalization. 


\section{Notas preliminares}

Desde antes de su novela Los parientes de Ester (1978), en varios de los cuentos de Luis Fayad se observan acercamientos que retratan la cotidianidad compleja de la capital colombiana, todos ellos basados en las discrepancias inmersas en los procesos de modernización y urbanización:

[...] el caso de Bogotá es emblemático de las contradicciones entre modernismo socioeconómico y modernidad cultural, las cuales generan formas y resoluciones literarias diferentes de acuerdo con las memorias históricas y culturales que se invocan en los procesos de enunciación. Dichas contradicciones son en gran parte el motivo desencadenante de casi toda la producción narrativa de Luis Fayad (1948), quien vive de niño el desajuste de Bogotá, como estudiante de la Universidad Nacional participa de sus movimientos ideológicos, la mira luego desde Europa, la lee, la escucha, la describe, la narra y la construye de nuevo, precisamente, los bordes, los desplazamientos y los espacios marginales que Fayad percibe en su ciudad, así como las búsquedas y fracasos de sus personajes, los lenguajes que reproduce o descubre y las estructuras sociales que representa, se constituyen en elaboraciones textuales que unas veces son mediaciones reflejas de Bogotá y otras, prefiguración de su imaginación (Figueroa, 2009, pp. 292-293).

La problemática social y económica de nuestras ciudades es la semilla que el autor utiliza para desarrollar sus relatos. En ese sentido, el escritor retoma sus vivencias en la capital para verterlas a la literatura y ficcionalizar la realidad. Fayad es un autor que ha plasmado con fidelidad la identidad bogotana al hurgar dentro del tejido social y advertir una sociedad hendida y conflictiva.

En este estudio sociocrítico me interesa, al tomar como base teórica una perspectiva interdisciplinaria, adentrarme en tres de sus relatos ("El entierro de Mico", "Un cuento para Manolo" y “Tigre”), en los que el eje de la acción recae en grupos marginales juveniles de una Bogotá en proceso de cambio durante las décadas de los sesenta y setenta. De acuerdo con Figueroa (2009), estos textos conforman una trilogía en la que la calle y la interacción de las diferentes clases sociales con ella son uno de los puntos más significativos. En estos cuentos se revelan una sociedad fracturada $\mathrm{y}$ un proyecto modernizador suigéneris:

Bogotá hace parte de un circuito complejo de ciudades latinoamericanas que ofrecen una serie de imágenes y voces en las que se mezclan diferentes influencias culturales. Estas urbes están ahora imbuidas dentro de diferentes procesos en los que conviven aun rezagos de una premodernidad perenne y una modernidad inconclusa. Esa cohabitación entre el ayer y el hoy, entre la ruralización de la ciudad y a su vez la misma urbe que se agiganta sin planificación invadiendo los cerros tutelares, en el caso de Bogotá, no solo se ve palpable en las calles, en los barrios periféricos, sino en cualquier área de estas megametrópolis (Bernal, 2018, p. 22). 
Fayad rememora realidades y mantiene viva una especie de archivo histórico de la ciudad dentro de un periodo temporal en el que Bogotá se hacía cada vez más densa. Dentro de ese proceso, vale la pena subrayar cómo la ciudad mutaba y de qué manera su población se incrementaba a medida que se acrecentaba esa marginalidad. Al respecto, Carlos Andrés Diaz Mosquera habla del aumento poblacional que en 1938 era de 330312 habitantes; en 1951 de 715250, y en 1964, una década después, espacio temporal en la que se desarrollan los cuentos a tratar, la población ya era de 1697311 habitantes. Ese masivo cambio en la población germinó zonas marginales y un recrudecimiento de una población flotante desatendida por el Estado, que ya para ese entonces se podría traducir en mendicidad, inseguridad, barrios de invasión, niños de la calle, entre otras consecuencias negativas. Diaz Mosquera (2009) no solo le brinda importancia a la aparición del individuo marginal, sino también a su entorno, al contexto que él denomina como "escenario de disputa por el derecho a la ciudad". Es decir:

La categoría de "Marginalidad Social urbana" no solo contiene la denominación de unos sujetos particulares como pobladores urbanos, sino que también está complementada por el espacio específico de su desenvolvimiento, el lugar de sus asentamientos que estaban antecedidos por luchas culturales, sociales, políticas y jurídicas, es decir El Barrio (p. ఠ). ${ }^{\mathrm{I}}$

En el caso de los textos de Fayad, estaríamos hablando de zonas definidas del centro de Bogotá: la calle 19 o la Avenida ciudad de Lima, la carrera décima, por ejemplo, e igualmente barrios cercanos a esta zona y localidades del sur de la ciudad. Dentro de ese espacio nos encontramos con una radiografía de la vida callejera desde las voces de la marginalidad, desde la oralidad de los protagonistas que cuentan sus aventuras de vida sin la mediación de voces que los juzguen o maquillen.

\section{Tres narrativas fundacionales como punto de partida}

La literatura que ilustra a la capital colombiana tiene numerosos autores que de diferentes maneras han representado la ciudad como un espacio particular, en el que se desencadenan disímiles situaciones, y a la vez se muestra como un lugar en el que sus habitantes están en continua evolución. La ciudad no se detiene jamás y su efervescencia es permanente. La literatura que refleja esta máxima también lo es; evoluciona y se trasforma mientras consigna en la ficción cómo la ciudad cambia, se camufla, cómo se altera la cotidianidad de sus habitantes, sus vivencias, miedos y pasiones. Al hablar de

1 Con miras a ampliar esta problemática, consultar América Latina: periferias urbanas, territorios en resistencia (2008), de Raúl Zibechi. 
los autores más representativos y cercanos a la obra de Fayad, debo mencionar algunas obras para llegar a un entendimiento de lo que ha sido la capital colombiana y cómo se ha plasmado en las páginas de varias narrativas durante esa época específica. Aquí hago hincapié en el binomio de un tipo de ficción que se identifica con la realidad misma, y cuyos escenarios y protagonistas se pueden explorar en los vericuetos de la ciudad. En esa ruta, debo iniciar hablando de la novela del mismo autor, Los parientes de Ester. En esta obra de Fayad se trenzan las dinámicas de una urbe en los albores de la década del sesenta, un relato que toca las referencias políticas y sociales de aquella época:

El principal valor que ha sido atribuido a esta novela, y que aún conserva, es su capacidad de representación de la sociedad colombiana a partir de recursos estilísticos y estructurales que parecen simples pero que se concentran justamente en presentar una ciudad y su historia a través de la intimidad de los personajes urbanos que conducen la trama [...]. Los parientes de Ester es una novela corta compuesta por dieciséis capítulos en los que se relata la vida de una familia de clase media bogotana que sufre las consecuencias económicas y sociales características del periodo político del Frente Nacional (Mejía Correa, 20I2, pp. 130-I3I).

Cercana a esta obra en términos cronológicos en los que se transcurre la novela de Fayad, incluyo Probibido salir a la calle (1998) de Consuelo Triviño, que a través de la voz de una niña describe las vivencias de una familia de origen campesino que se enfrenta a una Bogotá cada vez más insensible. En el texto de la autora colombiana la ciudad cambia a la par de las transformaciones que sufre la familia y las crisis lógicas que experimenta la narradora. Al respecto, Yadira Segura (2018) habla de una ciudad que no dejaba de ser la "Hécate de las tres caras, sombría, tenebrosa y prolífica" (p. 90). Una definición que encarna tres dimensiones de un espacio urbano que ya se vestía con una personalidad de gran ciudad latinoamericana: oscura, retadora pero fascinante. Siguiendo con esta periodización, es perentorio nombrar a Sin remedio (1984) de Antonio Caballero, libro que ha sido considerado para muchos como la novela de Bogotá o la Bogotá misma, como lo decía Alberto Quiroga (1999) en la desaparecida revista cultural Número: "Pocas novelas se han escrito sobre Bogotá. Sin remedio no es sobre Bogotá: Es Bogotá” (p. 95). Una narración que realiza aproximaciones a la idiosincrasia bogotana, en especial a una oligarquía corrupta y discriminatoria que ha ostentado históricamente el poder en el país.

Además de los límites temporales y temáticos que he fijado para estas obras, es fundamental mencionar que todas retratan eventos vinculados con grupos excluidos socialmente o clases populares que por diversos motivos son marginalizados. En la novela de Fayad, Los parientes de Ester, se narra el declive de una familia que después 
de la muerte de la madre cae en desgracia y afronta todo tipo de carencias. En el texto de Triviño, la protagonista de la historia, habita el sur de la ciudad, lugar tipificado como un espacio pobre, obrero e incluso semirrural. Por su parte, en Sin remedio se observan prostitutas migrantes, delincuencia, pobreza y una contemplación prejuiciosa de varios de los amigos y miembros de la familia de Ignacio Escobar (protagonista) hacia ciudadanos de capas populares.

Mi propuesta, entonces, tiene que ver con el análisis de la representación literaria de una Bogotá que ya para ese entonces establecía y detallaba las características ambiguas de "la experiencia real" en cuanto a la convivencia de sus ciudadanos, como también dentro de la observación de sus espacios urbanos, en los que se reconoce una ausencia del Estado. Pienso en aquella idea de Beatriz Sarlo (2001) cuando refiriéndose a Buenos Aires hablaba de que: "el Estado, pese a los reclamos y pese a las intenciones de los gobernantes, no está en condiciones de hacer aquello para lo cual fue instituido” (p. 56).

Para este tipo de temática, es importante tener como referente también las obras de José Antonio Osorio Lizarazo (1900-1964). Aunque este autor precede a todos los anteriores citados, sus obras están relacionadas con la marginalidad y con el despliegue de espacios y miembros de la sociedad que habían sido constantemente marginados en la literatura. En su obra hay un redescubrimiento y una apuesta democrática, en el sentido de una literatura que da cabida a diversos componentes de la sociedad y que tiene un carácter político y social al enseñar una Bogotá, que para ese entonces ya revelaba una creciente discriminación.

Los tres relatos escogidos para esta investigación aparecen en el segundo libro de cuentos de Fayad titulado Olor a lluvia de 1974. Estos trabajos anteceden a su gran novela urbana indicada al inicio de este trabajo, y como lo menciona el crítico José Manuel Camacho (2019) —al referirse al investigador Figueroa-, se aprecia desde ese entonces el interés de Fayad por explorar y reflexionar acerca de ciertos sectores de la población urbana:

Frente a su primer libro, lleno de pueblecitos ardientes y mundos rurales miserables, en este se produce un acercamiento a Bogotá (Figueroa, 2009), ciudad que ha crecido de forma compulsiva, aunque no ha sido capaz de modernizarse ni socialmente, ni culturalmente, lastrada y apegada a sus tradiciones, a sus ritos y costumbres; una ciudad que se ha llenado de inmigrantes provincianos, gente de toda condición y pelaje que ha llegado hasta sus barrios huyendo de la violencia, gente desesperada y estigmatizada con graves carencias sociales, afectivas y familiares, que no pueden volver atrás porque la violencia no les permite una segunda oportunidad en sus respectivos solares de origen (p. 32). 
Vemos entonces, como lo describe Camacho, que las fuentes de inspiración para Fayad aparecen a partir de dos temáticas muy concretas; una, la migración campo-ciudad que surgió principalmente después del periodo histórico llamado la Violencia en Colombia (1948-1958). Y la otra, como consecuencia de la anterior, tiene que ver con la relación tensa entre este tipo de nuevos ciudadanos que por razones obvias aún lleva rezagos de su vida anterior en el campo, y que, al llegar a la gran ciudad, choca con una realidad que en muchas ocasiones los convierte en seres que navegan entre el desarraigo y el desprecio.

\section{"El entierro de Mico"}

Este texto aborda un periodo de la historia de la ciudad que marcó a muchas generaciones de bogotanos y que fue un hecho observable a tal punto de considerársele como algo normal. Penosamente, el Estado, como tantas veces, nunca ejecutó un plan real de inversión social para solucionarlo. Los ciudadanos de Bogotá, y en menor grado de otras ciudades grandes de Colombia, por varias décadas observaron niños de la calle que habitaban en la urbe misma, robando, mendigando, durmiendo bajo los puentes, en las esquinas y en los parques. Parte del paisaje de esa ciudad de entonces tenía siempre ese panorama, como parte de una curiosa regulación de lo anormal. El arribismo colombiano, siempre eurocentrista desde tiempos coloniales y después muy proclive a la cultura popular norteamericana, bautizó a estos niños con el galicismo de "gamines”, palabra que en francés significa originalmente chiquillo de la calle o muchachillo ayudante de obreros. Pues bien, dentro de la idiosincrasia de aquellos días, la denotación despectiva hacia ellos, pero afrancesada, quizá para hacerla irónicamente más exclusiva, evidenciaba la indolencia de los gobiernos de turno y la poca sensibilidad de un gran sector de la sociedad que los distinguía entre el temor por considerarlos delincuentes o drogadictos, y a la vez,con alguna falsa mirada lastimera y vergonzante por su naturaleza, pues a pesar de todo eran vistos como chicuelos dulces y pícaros. Bajo este contexto, en el cuento se pinta la crueldad y la marginalidad de la vida callejera bogotana dentro de un grupo de gamines que es descrito por el autor al mostrar sus hábitos y prácticas. Niños que solían deambular por las calles y avenidas principales mendigando un mendrugo de pan, una gaseosa, las sobras en algún restaurante; subiéndose al transporte público de la ciudad a cantar o simplemente a pedir monedas; muchachos que alcanzaban la adolescencia o la temprana adultez, ya diestros en los 
robos, los raponazos o atracos. Este tópico de marginación juvenil y su inmersión en la calle que resultaba en procesos delictivos también tuvo, en su momento, su furor en el cine latinoamericano, incluso nacional. Es así como Ciro Durán, cineasta colombiano, llevó a la gran pantalla una película documental — Gamín (1977) — en la que se mostraban niños en situación de calle que vagabundeaban y delinquían en diferentes zonas de Bogotá. La cinta proyectaba imágenes descarnadas de las vivencias y condiciones por las que pasaban estos chiquillos y adolescentes. Estos temas en el cine regional también desencadenaron críticas, pues en aquella época fueron acusados de explotar la miseria latinoamericana sin mayor estudio e investigación, con miras a cautivar públicos europeos y norteamericanos. Al respecto, el cineasta argentino Luis Puenzo los denominó como "pornomiseria". ${ }^{2}$ Para él, este tipo de cine no reflejaba el "fuego interior” que permitía a los latinoamericanos, a pesar de tanta desgracia, reconocerse como seres “más vitales y más vivos que muchas cosas de Europa” (León, 2005, p. 77).

Pero sin duda una cinta líder que trató esta problemática de la delincuencia juvenil urbana fue Pixote (1980), del director argentino Héctor Babenco (1946-2016). La historia narraba con realismo las vivencias del protagonista (Pixote), un niño que vivía en las calles de São Paulo, vagando y robando. La película revelaba todo el dramatismo de este contexto, en el que el escenario, además de las esquinas paulistas, evidenciaba también el mundo marginal de las trabajadoras sexuales, las bandas juveniles, las mujeres prostitutas transgénero y el comercio sexual masculino. A su vez, la calle se exaltaba no solo como lugar de convivencia y trabajo, sino también de recreo y ocio. Las vivencias de la calle predominaban, pero también se hacían acercamientos a otros lugares contiguos al drama de los protagonistas: las habitaciones miserables en donde las trabajadoras sexuales atendían a sus clientes; las favelas y su violencia desenfrenada, o el reformatorio juvenil que terminaba siendo peor que las mismas calles. Este mundo reflejado en la pantalla gigante llamó la atención de los espectadores, que comenzaron a redescubrir la dramática situación de miles de niños y adolescentes en diferentes urbes del continente.

Siguiendo esta línea que enmarca el contexto del argumento de los cuentos de Fayad, la trama de "El entierro de Mico" se concentra en el posible entierro de uno de se le relacionó con el término de "pornomiseria". El denominado "Grupo de Cali" integrado por el escritor Andrés Caicedo y los cineastas Carlos Mayolo y Luis Ospina fue un fuerte detractor de este tipo de cine. 
los líderes más queridos y jóvenes (Mico) de una banda de gamines que, sin saberse con certeza si ha fallecido o no, focaliza toda la tensión del escrito. El cuerpo de Mico, bajo una lluvia leve que le da un toque de mayor tristeza al evento, es el centro de un ritual en el que sus compañeros y otros niños se unen al cortejo que recorre la ciudad y cuyo destino es llegar a uno de los cerros de esta Bogotá trágica e invisible para muchos.

Los ojos de un narrador en tercera persona nos permiten acercarnos a la vida de estos niños que irradian, como en la realidad misma, una mirada de picardía que les sirve para sobrevivir en ese mundo. Mico se encuentra en un estado de quietud que nadie en el relato sabe a ciencia cierta a qué se debe: "Esa vez ni siquiera Portela pudo explicar qué le sucedió a Mico" (Fayad, 1974, p. 49). En una especie de procesión, el protagonista es transportado en hombros como un héroe legendario mientras todos sus acompañantes, niños y adolescentes, le rinden tributo en silencio como muestra de respeto y solidaridad a uno de los suyos que se ha ido o que está camino a despedirse: "A Mico lo cargaron desde el centro hasta el cerro los mayores, turnándose no porque se cansaran sino porque todos querían llevarlo" (p. 9). La historia de Mico es un fragmento de una fotografía rasgada en un momento de su vida, apenas un instante que el autor visibiliza y que el lector descubre a partir de cuadros de una Bogotá descrita con imágenes entre tiernas y trágicas:

Peto era hermano de Portela y como pertenecía a los más pequeños era muy amigo de Mico, se la pasaban juntos y cuando todos se separaban ellos se iban por ahí, a veces en compañía de otros pequeños pero siempre los dos. Sabían a qué cafetería y restaurantes entrar y conocían con solo mirarlo al cliente que les daría un pedazo de bizcocho o que les permitiría coger las sobras de los platos. Se divertían viajando en el parachoques trasero de los vehículos o sobre un cartón que les servía de coche luego de asirse a la parte posterior de los buses, pero no se alejaban mucho porque todavía eran muy pequeños aunque ya se habían arriesgado en unas ocasiones para salir a otros barrios. La primera vez estuvieron en Chapinero y después más abajo de San Victorino donde se aventuraron solos porque a Chapinero los acompañó Crespo, que era de los mayores (pp. 49-50).

La historia de Mico tiene una entrada profunda que es el centro temático de todo el escrito, cuyo único hecho es su mítica despedida de la ciudad hacia las zonas conurbanas de Bogotá. Irónica imagen esta cuando lo contrario —esa migración a la ciudad- parece indicar parte de la problemática social que envuelve todo el relato. Aquí los acompañantes de Mico, sus amigos y conocidos, lo alejan de su nicho urbano, donde malvivió, y lo apartan de su pasado para instalar su cuerpo en los cerros tutelares de la gran ciudad. Pero mientras el centro de la historia es esa travesía, los detalles que le brindan dinámica a la historia se basan en la narración de la cotidianidad del protagonista y sus amigos: 
El que más se recostaba era Ñato porque el día anterior se había clavado un vidrio en un pie al tratar de colarse en la plaza de toros. Hacía un año que había usado zapatos por primera vez pero se le gastaron tan pronto que no alcanzó a perder la costumbre de andar descalzo, y cuando buscaba por dónde entrar burlando la vigilancia sintió la punzada en el pie, de modo que tuvo que quedarse sentado en un prado mientras se le pasaba el dolor [...]. Para los vigilantes nocturnos era un oficio estar despertándolos a cada rato porque se quedaban dormidos contra las vitrinas, especialmente en las que había más bombillos, pues no pegaba tan duro el frío, y cuando hacía mucho calor se desnudaban y se bañaban en las piletas mientras la gente los contemplaba divertida, hasta cuando llegaban dos o tres policías y ante los observadores aún más divertidos los espantaban porque si los prendían no sabían qué hacer con ellos (pp. รI-ร2).

Dichas escenas demuestran la desidia con que la sociedad en general observó inmóvil esta problemática social y la hizo propia como un hecho común dentro del tránsito de la modernidad urbana, que dejaba de lado la preponderancia de los pueblos, para darles paso a las llamadas grandes ciudades. Y aquí hablo de "hecho común" como algo pintoresco o acaso gracioso que se relacionaba con la ciudad misma, en este caso Bogotá, y que en lugar de ser visto como lo que era, una tragedia, se miraba de reojo, con prevención y se le daba la connotación de algo folclórico que hacía parte del paisaje de nuestras ciudades: niños juguetones, abandonados y sin futuro, "viviendo" en las calles, haciendo "pilatunas" ante la indiferencia social. En este debate, vale recordar una cita de un estudio de Ivannsan Zambrano y Rita de Cássia Marchi (2014) en la que plantean que

En la ciudad, el otro, aquel que no pertenecía a la elite capitalina o medianamente a las clases medias, era visto con recelo. La actitud de los citadinos respecto al campesino o al mismo gamín reflejaba la indolencia, el miedo y el desprecio por quien no se correspondiera con los ideales del hombre moderno, civilizado y promovido (p. 62 ).

En dicho trabajo se nombra una obra de Manuel Zapata Olivella, Detrás del rostro (1963), que narra la agonía de un niño desamparado de la calle que, moribundo después de recibir un balazo en la cabeza, durante cinco días no es auxiliado por nadie, hasta que finalmente es recogido por el protagonista. Con la anterior descripción, tomada del texto del autor colombiano, se pone de manifiesto nuevamente la falta de humanidad del prójimo y en especial la apatía del "poblador urbano" (p. 62). Es decir, dentro de la creación del mundo de la ciudad, de la gran urbe, la figura de "el otro" es ajena o simplemente invisible. Dicha novela, que enfrenta la indiferencia que se vive en la ciudad, resulta oportuna para articular con este cuento de Fayad cómo Mico transcurrió en vida, e incluso durante su muerte, como un ser X, o NN, como se suelen nombrar en las tumbas a los occisos desconocidos. 
Y es que en el mismo día de la despedida de Mico, todo el acontecimiento pasa totalmente desapercibido en la ciudad, espacio en donde priman la individualidad y el anonimato. Con esta pesada carga de desidia, los amigos de Mico, a pesar de la tristeza, tienen que regresar a la inclemencia de la calle a afrontar el frío cemento y la orfandad de la sociedad. La historia de Mico nos hace pensar en un cuento de mucha trascendencia en la literatura latinoamericana, "Los gallinazos sin plumas" (1955), de Julio Ramón Ribeyro, en el cual unos niños en circunstancias similares se ven obligados a buscar su sustento en las calles de Lima, en este caso bajo la explotación de un adulto. Al respecto, Porfirio Mamani Macedo (2004), habla del drama de los niños y jóvenes que se ven forzados a vivir una realidad que no les pertenece: un mundo de adultos bajo condiciones "infrahumanas". Para Mamani Macedo, Ribeyro introduce este tipo de conflicto en varias de sus narraciones:

El narrador sitúa a los niños, dentro de un contexto social inmerso de marginalidad, donde los adultos aparecen como seres a quienes no les interesa en absoluto el destino, ni el mejoramiento social de estos niños, los someten a un estado de dependencia inversa, es decir que los niños les sirven como una fuente de sustento. Esta relación de dependencia inversa, a los adultos les permite no trabajar o trabajar menos como el caso de Padrón, el padre de Paulina, en el cuento "Interior L" (p. II7).

Aunque las circunstancias en el cuento del escritor colombiano son diferentes, el nudo central del texto toca también esa "dependencia inversa" pero vista desde la perspectiva de niños de la calle que no son explotados por un adulto en particular (al menos no en esta historia), pero sí son sacrificados dentro de un contexto urbano, cuya sociedad les tira apenas unas migajas, los observa a la distancia como parte de un paisaje intrínseco de la urbe, y a la vez, sin asumir su responsabilidad, los presume solo como niños traviesos cuyo único destino seguirá estando en las calles.

\section{"Un cuento para Manolo"}

En este relato, Fayad le da vida a un jovenzuelo delincuente que le rinde cuentas a otro acerca de los fracasos de su oficio. El narrador, avergonzado por su poco éxito en una temporada de "trabajo", ruega encarecidamente a su interlocutor que le crea, pues las cosas van de mal en peor, debido a que es muy difícil llevar a buen término sus acciones delictivas. Quizá por su misma ineptitud, o acaso, como el mismo argumenta, por la prevención y recelo que ya tienen los ciudadanos ante la inseguridad urbana. Este tema de la delincuencia bogotana, en particular, aquella juvenil, vuelve a ser foco 
de interés para el autor. Habría que pensar, por ejemplo, que, para Fayad la capital del país se percibe con una atmosfera de inseguridad e incertidumbre, un contexto con el que ha tenido que convivir el ciudadano promedio. En relación con esto, en la ya citada novela Los parientes de Ester, en algún momento el narrador describe una conversación entre dos personajes que apuestan a la idea de abrir un restaurante en la ciudad,y una de las voces recalca la imperante necesidad de armar a los guardias para proteger el negocio: "porque Bogotá está llena de gamines y locos" (Fayad, 2019, p. 249). En cuanto a esto, es obvia la invitación que hace el autor a repensar la correspondencia que tiene el ciudadano de a pie con la calle, es decir, la vía y el espacio público como lugares de riesgo y peligro. Este es un asunto que no resulta ajeno para ninguno de los escritores más representativos dentro de la ficcionalización de Bogotá durante esa época; hablo aquí de Consuelo Triviño, que desde el título de su novela advierte que salir a la calle puede ser una aventura sin regreso; o los recorridos que realiza Ignacio Escobar en la novela de Antonio Caballero (Sin remedio), en los que se visibiliza toda una fauna urbana que, desde ese entonces, desenmascaraba la realidad social no solo de Bogotá, sino de muchas otras ciudades colombianas. ${ }^{3}$ En cuanto a esto, en una nota aclaratoria de la novela de Fayad, José Manuel Camacho (2019) afirma:

A partir de estos pequeños detalles se vislumbra la crítica implícita a la inseguridad que se vive en amplias zonas de Bogotá, como consecuencia del llamado periodo de la Violencia, los desplazados desde las zonas rurales, los primeros coqueteos con el narcotráfico y las bolsas de marginalidad generadas por el propio sistema capitalista y la carencia de verdaderas políticas de protección social (p. 249).

Aquí las instantáneas de Bogotá se van develando por medio de la larga intervención del narrador que documenta su tesis por medio de diferentes hechos en los que él mismo ha participado. Aparecen así los alias de los integrantes de la banda, las peripecias callejeras, los lugares de encuentro, las relaciones de poder entre los jóvenes maleantes, los choques con la policía, el viacrucis de vivir en y de la calle, entre otras aciagas circunstancias. El narrador, llamado "el Chiquito", insiste en su inocencia, pues teme que su jefe pueda pensar que lo engaña para quedarse con el botín. Lo 
valioso en lo literario e histórico, en términos de la memoria de la ciudad, recae primero en la construcción realista de los hechos y las situaciones que vive este grupo marginal que se enfrenta a un único derrotero como forma de supervivencia, que es la transgresión de la legalidad por medio de sus atracos y robos en las esquinas. En esas imágenes, por medio del narrador, Fayad logra que el lector detalle los laberintos de la ciudad, en especial los del centro de la misma, y así el muestreo de una Bogotá insegura y sin ley es entendida como una postal parcial de la ciudad de aquellos días. El segundo punto a considerar que resulta sustancial es al aspecto oral en el que está cimentado el relato. El personaje que le rinde cuentas a su aparente líder emplea un sociolecto y una serie de germanías propias del núcleo social al que los maleantes pertenecen; de ese modo le brinda verosimilitud y mucha autenticidad al discurso que es entronizado por esta peculiaridad. El uso y abuso de términos como la expresión "Manolo hermanolo", por ejemplo, ${ }^{4}$ logran, a través del largo aliento de la participación del narrador, tallar una serie de momentos que en verdad encierran una sola escena en la que un personaje habla por largo rato mientras el otro, implícito, escucha la extensa perorata. En el sentido del lenguaje que usa el autor, podría decirse que esta es una de las primeras aproximaciones a lo que en décadas posteriores fue parte fundamental del lenguaje de otros delincuentes, sicarios y pistoleros locales que no solo tuvieron una identificación con el aspecto urbano de las ciudades, sino que lo llevaron a la literatura y el cine, informando una determinada realidad social. Hablo aquí, por ejemplo, del auge del parlache en varias de las novelas que se escenifican en la Medellín de los años ochenta o noventa. En consecuencia, en este cuento de Fayad se evoca la realidad del habla de un grupo marginal urbano, muy específico de la Bogotá de entonces, cuya influencia pudo haberse desplazado a otros contextos geográficos como sucedió con el fenómeno del parlache. ${ }^{5}$

En otra perspectiva, la vida de la gallada que se representa en la historia puntualiza lugares de la ciudad como la calle décima, vía arteria del centro de Bogotá, y juega con aconteceres cotidianos. Un ejemplo de lo anterior lo leemos cuando

$4 \quad$ En el relato aparecen términos como "perrada": traición; "embotellar": ir a la cárcel, "moler": trabajar; "echar pistero": mirar/observar con detenimiento en la calle para buscar víctimas; "tumbar": robar; "chuzar": herir con arma cortopunzante; "atortolarse": ponerse nervioso; "levantar para la papa": trabajar para comer; "tombos": policías; "manito”: compañero.

5 Aunque en el cuento no se observa un corpus sólido de germanías que permitiesen hablar de un sociolecto establecido, sí existe un grupo de términos y palabras utilizadas dentro de una jerga particular. 
el autor pinta miradas y situaciones insinuantes del acontecer de algunos de los personajes: "que la Josefina todavía está buena, déjala quieta que es solo para mí, que tiene buenas piernas, que ponga más duro el radio Josefina divina, no la molestes si no quieres tener lío conmigo, que miren como se mueve para ponerlo a uno eléctrico" (Fayad, 1974, p. 63). Las dos únicas mujeres con alguna relevancia en un relato contextualizado dentro de un mundo de hombres y sus aventuras son Marcela y Josefina, quienes surgen como oasis y brindan, por momentos, una tregua a los individuos que están relacionados con el accionar delictivo en las calles. Las dos mujeres se reúnen con el grupo en sus tiendas de barrio: Marcela, cuidada por su padre que no quiere que su hija se relacione con vagos, y "la Josefina", que se entiende como una mujer mayor pero todavía sugestiva.

Dentro del largo vuelo que toma esta historia de Fayad, se establecen evocaciones realistas de hechos y escenarios que sirven para apoyar la tesis de Chiquito. Por medio de sus amigos, el Negro, Ciro, y el Loco, el personaje principal, que lleva la voz de los hechos, inicia y termina su monserga con una única e irónica idea: que él es honesto y que lo que trae del pillaje es lo único que había, "Manolo hermanolo".

\section{"Tigre"}

Desde el título de este cuento, nos vemos ante el repaso biográfico de un joven que, por carencias económicas, la compleja situación de su familia, una madre lavandera, un padre que no se nombra, comienza su prolífica carrera en la delincuencia. Desde temprana edad el personaje es apodado Tigre, alias que arriba desde tiempos de la escuela elemental gracias a sus destrezas felinas para correr, saltar y en suma para superar cualquier adversidad como una verdadera fiera urbana. Infortunadamente, la agilidad y la vivacidad del personaje solo le sirven para ejecutar tareas de orden ilícito. Tigre, como protagonista, nos da una inspección de lo que era el proceso de maduración y consolidación de pasar de ser un simple ratero hasta convertirse en un avezado ladrón. Nuevamente aquí, el escritor nos deja trazos de la vida de un personaje marginal dentro de una ciudad que poco a poco se va transformando a la par de las novedades del protagonista. Esos trazos dibujan escenas de desencuentros entre bandidos, anécdotas de fechorías y pruebas dentro de una colectividad excluida que únicamente parece interactuar con la sociedad a partir de sus faenas ilegales. Tigre nos enseña una realidad de página roja que se abre en un diario sensacionalista y que 
encumbra los desapacibles aconteceres de un antihéroe urbano que solo pareciera conocerse en los bajos fondos, en las crónicas policiacas o en los tebeos gráficos del género negro.

La historia, como las anteriores, maneja una técnica bitemporal. La narración se establece en un presente que se desarrolla a partir de la última aventura del personaje: "Atrás quedaba la avenida iluminada. Por la calle que corría ahora era oscura y tal vez por eso la avenida que dejaba parecía llena de luz" (Fayad, 1974, p. 65), y luego empata con la descripción final de los últimos párrafos del relato; estrategia narrativa esta que Fayad implementa en las otras dos historias aquí analizadas. En medio de esas temporalidades emerge la trama sustancial, la vida del protagonista. Dentro de ese prontuario de Tigre asoma una sentencia que aparece por medio de la voz de uno de sus jefes y que es clave en la identificación directa de una contundente crítica social: "no se ponga así, quitarle al que tiene mucho no es pecado, imagínese a su mamá trabajando tanto para ganar una miseria" (pp.66-67). Sucede que, durante un momento de crisis y agobiado por su consciencia, el protagonista es calmado y aconsejado por su mentor que lo anima, y de manera clara justifica su accionar al sugerir que algunos tienen de sobra y otros no tienen nada. En esta escena se abre una discusión de tipo social y político, pues dentro del relato el lector puede empatizar, o al menos entender, las razones del accionar de Tigre. Es decir, el personaje como tal y sus actos no son una causa, sino una consecuencia. Por consiguiente, tendríamos que regresar a un tema primordial en todas las tres historias, que tiene que ver con la realidad de una ciudad, de una nación injusta y socialmente muy desigual. En el caso de Bogotá, el contexto que ocupa este y los anteriores cuentos, tendríamos que remitirnos a un proceso de modernización complejo y desarticulado que tristemente se sigue observando en el presente, y que resulta extensivo a todo el país:

Es verdad que el crecimiento desmesurado de las ciudades es un mal planetario y les ha significado desafíos inmensos a todas las sociedades. Pero es difícil encontrar un caso más traumático que el proceso de crecimiento de Bogotá, y la prueba la podemos encontrar en el desorden de sus calles, en el caos urbano, en la crisis del transporte, en la hostilidad generalizada, en los altos índices de pobreza, en los alarmantes niveles de indigencia, en la corrupción de la administración, en la inseguridad (Ospina, 1997, p. II7).

La anterior cita de Ospina refleja el acontecer de Bogotá que, desde la época narrada en el cuento de Fayad, da ya indicios de una gran aglomeración urbana con múltiples problemáticas económicas y sociales. Todo un ambiente prolífico para el surgimiento 
de muchos de estos personajes que saltan de la realidad a la ficción. En este cuento, el protagonista parece tener desde su niñez un solo camino, y ese manual indica que robar, como le decía su jefe, es de cierta manera balancear una sociedad injustamente asimétrica. Y en ese proceso, que es entendido por el lector, Tigre se enfrenta a pulir sus destrezas desde las primeras páginas de la historia:

El jefe dijo que haría un ensayo, tenía todo preparado, que resolviera de una vez si se arriesgaba o no, el jefe mismo lo ayudaba a subir la tapia mientras el compañero y los otros dos campaneaban por si venía alguien, él contestó que sí era capaz, tal vez por vergüenza a decir que no se atrevía pero en todo caso la prueba no podía haber salido mejor (Fayad, 1974, p. 66).

La realidad de Tigre es una sola, la de sobrevivir en un mundo que únicamente le brinda encrucijadas. Y en ese contexto de gran delincuente hasta las mujeres lo buscaban, sin duda una caracterización acertada de un tipo de personaje villano con aspectos muy masculinos, aparentemente rudo, audaz, exitoso en su labor y asediado por el género femenino:

El compañero que le sacó cuchillo porque dizque le quería quitar a Leonor, pero era Leonor la que le estaba coqueteando a Tigre, haciéndole ojitos y el a fin de cuentas era hombre, qué hacía, si no se mostraba por lo menos un poco interesado le decían marica, seguro, pero él era muy hombre y por eso casi tiene su gran lío con el compañero, de cuchillo y todo porque el compañero no era de los que se ponía con pendejadas ni Tigre tampoco (pp. 69-70).

Importante mencionar que, en la secuencia de situaciones y descripciones de la vida de este personaje, existe una similitud con la trama del cuento "El indigno", de Jorge Luis Borges (1999), en el que el personaje principal, Santiago Fischbein, joven con miras a pertenecer a una banda de maleantes integrada por compadritos, se hace amigo del jefe, Francisco Ferrari, y poco a poco va asumiendo su nuevo rol, al igual que el personaje de Fayad. Aunque son varias las diferencias en cuanto al desarrollo y la resolución de las dos historias, además del contexto geográfico y temporal, se puede afirmar que en ambas existe un contexto deprimido que sirve como caldo de cultivo para el surgimiento de individuos, grupos sociales y comunidades marginales dentro de una atmósfera urbana en la que la ciudad latinoamericana revela problemáticas sociales y económicas que con el tiempo se fueron agudizando:

En el relato "El indigno", de la colección El informe de Brodie (1970), se exalta la figura del llamado "compadrito" y se describe el contexto urbano de época de algunos barrios de la ciudad de Buenos Aires. A partir de estos dos elementos se cuenta una anécdota cuyo eje temático es el episodio de una traición entre un delincuente novato y su jefe [...]. Pues bien, la ciudad en consecuencia sufrió 
diversos cambios y engendró paulatinamente nuevos espacios de (des)encuentros, en donde ciertas zonas se convirtieron en los aposentos de ciudadanos emergentes que surgieron gracias a las profundas transformaciones que se vivían en la sociedad de aquel entonces (Bernal, 2014, pp. 103, 104-105).

En otras palabras, tanto Fayad como Borges son testigos del funcionamiento y de la evolución urbana que no solo fecundó áreas complejas en términos socioeconómicos, sino que a la par dio paso a diferentes individuos marginales, como se lee en los dos cuentos. En “Tigre” se dibuja un tipo de habitante que se torna en un personaje urbano reconocido: el ladrón de barrio, el delincuente callejero, el atracador de la noche.

\section{Observaciones finales}

Dice el crítico Cristo Figueroa (2009) acerca de esta serie de cuentos que conservan temáticamente un eje común:

La trilogía de relatos conformada por "El entierro de Mico", "Tigre" y "Un cuento para Manolo" focalizan externa e internamente los ritmos de actividad, los conflictos y las pautas de comportamiento de seres marginados, gamines, ladronzuelos y bandas de rateros generados en el proceso de modernización de Bogotá. El motivo de la travesía por el centro y por ciertos barrios de la ciudad enfatiza el significado que la calle tiene para estos seres, en contraposición con su ausencia para las clases media y alta: mientras las primeras conciben la calle como el espacio asignado para el tránsito de vehículos o para ciertas convocatorias institucionales y las segundas la asimilan con un lugar en extremo peligroso, los gamines y los raponeros la identifican con la sobrevivencia, situs que origina “trabajo" y “descanso", crea vínculos y permite enfrentar la vida en medio de riesgos y persecuciones (p. 299).

El comentario de Figueroa sirve para resaltar dos aspectos que son fundamentales para comprender interiormente la propuesta estética del escritor en estos relatos. En primera medida, queda claro que en estos textos se refleja el vacío y la incomunicación que se establece entre las diferentes capas sociales de una Bogotá clasista (reflejo de toda Colombia), que parece ya desde ese entonces perpetuar una estructura social de orden colonial, con un índice de desigualdad perturbador. En segunda instancia, sobresale que en los tres textos discutidos existe una fotografía fiel de una realidad urbana que se vivió en aquellas décadas y que en el presente amerita considerarse como parte de la memoria de la ciudad. Fayad problematiza acerca de las dificultades de la connivencia urbana en Bogotá; controvierte e invita al lector a reflexionar acerca del drama de la orfandad de la niñez y la adolescencia que se observaba en el paisaje de la gran ciudad. Además, surge en estos escritos la inquietud de la calle como espacio de lucha, de supervivencia para un determinado grupo social 
que es ignorado por un Estado en crisis. El acercamiento a tal problemática emerge en la obra del autor a partir de lo urbano como una estructura nueva en el país en la que los individuos conviven de manera conflictiva. En ella surge el barrio como un subespacio de circulación, transacción social y comercial; la calle como lugar de tránsito, trabajo y mendicidad dependiendo del estatus del ciudadano, y finalmente el ciudadano: en el caso de estos relatos, un sujeto excluido. Ese personaje, abandonado desde su niñez, crea su nicho, su forma de comunicarse y su manera peculiar de resolver sus carencias malviviendo en la calle. Fayad realza una temática que es central en su obra, se vale de ella para pintar un fragmento de ciudad, un lienzo de una Bogotá que tuvo un ayer.

\section{Referencias bibliográficas}

Babenco, H. (productor), Babenco, H. (director). (1980). Pixote. Brasil: HB filmes.

Bernal, A. A. (2014). Reminiscencias de Buenos Aires, el compadrito y el arrabal en "El indigno". Variaciones Borges, pp. 103-117.

Bernal, A. A. (2018). Percepciones e imágenes de Bogotá, expresiones literarias urbanas. Madrid: La Mirada Malva.

Borges, J. L. (1999). El indigno. En El informe de Brodie. Buenos Aires: Alianza Editorial.

Camacho, J. M. (2019). L. Fayad. Los parientes de Ester. Edición crítica. Madrid: Cátedra.

Diaz Mosquera, C. A. (2009). Algunas características del proceso de urbanización de Bogotá desde 1950 hasta finales del siglo xx. Una mirada desde la marginalidad social urbana. Revista latinoamericana de estudiantes de Geografía 1, pp. 1-15.

Fayad, L. (1974). Olor a lluvia. Bogotá: La Pulga.

Fayad. L. (2019). Los parientes de Ester. Madrid: Cátedra.

Figueroa, C. R. (2009). Percepciones de Bogotá en la cuentística de Luis Fayad. Tabula Rasa 11, pp. 289-308.

Figueroa, C. R. (2012). La producción de Luis Fayad: conformación de otro canon en la narrativa colombiana de la segunda mitad del siglo xx. En C. R. Figueroa y C. E. Acosta (Eds.). Luis Fayad. La madeja desenvuelta (pp. 27-79). Bogotá: Pontificia Universidad Javeriana y Universidad Nacional de Colombia.

León, C. (2005). Cine de la marginalidad, realismo sucio y violencia urbana. Quito: Universidad Simón Bolívar, Corporación editora nacional y Abya Yala. 
Mamani Macedo, P. (2004). Visión de la vida de los niños en el mundo caótico de los adultos, en la narrativa de Julio Ramón Ribeyro. La palabra y el hombre 131, pp. 115-126.

Mejía Correa, C. V. (2012). La consolidación de la novela urbana en Los parientes de Ester de Luis Fayad. En C. R. Figueroa y C. E. Acosta (Eds.). Luis Fayad. La madeja desenvuelta (pp. 127-148). Bogotá: Pontificia Universidad Javeriana y Universidad Nacional de Colombia.

Ospina, W. (1997). ¿¿Dónde está la franja amarilla? Bogotá: Norma.

Quiroga, A. (1999). La hora de la verdad. Número, pp. 95-96, marzo-mayo.

Ribeyro, J. R. (1999). Los gallinazos sin plumas. En Cuentos. Madrid: Cátedra.

Sarlo, B. (2001). Tiempo presente. Buenos Aires: Siglo xxI editores.

Segura, Y. (2018). La construcción del monstruo. En M. A. Vázquez (Ed.). No era fácil callar a los niños. Veinte años de Prohibido salir a la calle, novela de Consuelo Triviño Anzola (pp. 89-105). Granada: La Mirada Malva.

Ventura, J. (productor) Durán, C. (director). (1977). Gamin. Colombia, Francia: Cinematográficas Uno e Instituto Nacional Audiovisual - INA.

Zambrano, I., y De Cássia Marchi, R. (2014). Narrativas sobre el gamín en Colombia: nuestra novela del desprecio. Uni-pluri/versidad 14 (3), pp. 59-69.

Zapata Olivella, M. (1963). Detrás del rostro. Madrid: Aguilar. 